\title{
Why Are They So Quiet? Exploring Reticent and Passive East Asian ESL Students in the U.S. Classrooms
}

\author{
Yuwei Wan \\ School of Foreign Languages, Jiangxi University of Finance and Economics, Nanchang, China \\ Email: wanyuwei@jxufe.edu.cn
}

How to cite this paper: Wan, Y. W. (2021). Why Are They So Quiet? Exploring Reticent and Passive East Asian ESL Students in the U.S. Classroom. Open Journal of Modern Linguistics, 11, 942-954.

https://doi.org/10.4236/ojml.2021.116073

Received: November 9, 2021

Accepted: December 18, 2021

Published: December 21, 2021

Copyright $\odot 2021$ by author(s) and Scientific Research Publishing Inc. This work is licensed under the Creative Commons Attribution International License (CC BY 4.0).

http://creativecommons.org/licenses/by/4.0/

\begin{abstract}
East Asian ESL students in the United States are frequently perceived as reticent, timid, and unsociable in class activities and discussions. The article reports a literature review investigating the possible causes of the actual condition of East Asian students' participative performance and finds out feasible accommodations to provide to them. Cultural background, foreign language anxiety, classroom norms, and gender/age are discussed as factors influencing students' willingness to speak in class. Accommodations regarding the issue include the use of written communication and online learning tools. Gaps and implications for future research are formulated in the end.
\end{abstract}

\section{Keywords}

East Asian Students, Reticent and Passive, Class Participation, Accommodations, Cultural Factors, Foreign Language Anxiety

\section{Introduction}

According to the statistics for the 2019/20 academic year released by Open Doors Report on International Educational Exchange (Institute of International Education, 2020), the number of international students enrolled in the U.S. higher education reached 1,075,496. Despite the influence of the Covid-19, the U.S. remained the top destination for international students, among which, approximately $40 \%$ are from East Asia. The top 3 places of origin of international students are China, India, and South Korea. However, East Asian international students in the U.S. frequently are perceived as reticent, timid, and unsociable (Shen, 2001; Takahashi, 2019). The most common assertions are that they are good at listening and taking notes, but reluctant to participate in class activities 
and discussions (Kim, 2006). Some existing researches affirm that East Asian students are sometimes reticent and passive learners in class, but they are talkative after class with peers from the same or similar cultural background (Tani, 2005: p. 1). In several comparable studies about Hong Kong students in English context class, where the courses were taught in English by native English speakers with high expectations to students' class participation, "the deathly silence" occurred when teacher asked open-ended questions in the lecture (Biggs, 1991: p. 3). More studies conducted in the U.S. also show the concern that East Asian students are unwilling to respond; they do not ask questions; and they are passive and over-dependent on the teacher (Tsui, 1996; Takahashi, 2019).

To some extent, there are no apparent negative consequences of this phenomenon. Few studies indicate that low participation will impede students' academic achievement, but the reticent behavior has been seen as "a barrier to the fostering of good learning practice" and "an obstacle to engaging with campus life and fully benefiting from studying in another country” (Tani, 2008: p. 345). Some other negative impacts may include poorer letters of recommendation from professors and insufficient preparation for further graduate study (Paulhus, Duncan, \& Yik, 2002). Hence, much research treats students' reticence and passivity as unsatisfactory and proposes possible solutions to encourage students to share ideas in or after class. However, most of the existing studies only provide a partial understanding of East Asian students' in-class participative performance, while students' behaviors are impacted by many factors, both intrinsically and extrinsically. This review article is significant in synthesizing relevant research findings and pointing out gaps and implications for future research. Moreover, it will attract more research interests in studying East Asian students' in-class participation, bringing pedagogical implications for future language teaching and learning.

To find out the causes of the problem and investigate accommodations to offer to Eastern Asian students, the study focuses on two main research questions:

1) What factors influence the participative performance of East Asian students in U.S. classrooms?

2) How can teachers provide accommodations to those East Asian English language learners?

\section{Similarities among East Asian International Students}

East Asian international students are all English language learners whose first language depends on their countries of origin. Geographically and culturally speaking, countries in East Asia like Japan, South Korea, and China often share something in common. Wang (2006) provided us with a historical point of view that most of countries in East Asia are pre-industrial societies with "a high population density, a long history as feudal societies, and a period of colonization or occupation by Western superpowers" (p. 71). Their shared historical and social background is one of the key factors that lead to their similarities in behavior 
and lifestyle. Also, it is widely acknowledged that Confucianism provided the common foundation for social behavior, ideals of government, and education to East Asian countries (Rošker, 2017: p. 45). Further, as Marginson (2011) noted, these countries all have been walking on the path from labor-intensive manufacturing to high-technology industry, which leads to rapid economic growth and rising prominence on the world stage (p. 592). Also, Choi and Nieminen (2013) suggested that these countries all share the view that education can drive economic growth (p. 170), which explains why an increasing number of East Asian students apply for Western colleges and universities to look for better education with the support of their whole family.

\section{Factors Influence Students' Participative Performance}

There are a numbers of causes that can lead to students' reluctance in participating in classroom activities. Cultural background, foreign language anxiety, classroom norms, and gender/age are commonly discussed as factors influencing students' willingness to speak in class.

\subsection{Cultural Factors}

Asian culture strongly influences students' thoughts and behaviors by intrinsically providing value, tradition, habits, and assumptions (Tani, 2005; Rošker, 2017). The differences in the nurturing process of Asian-heritage and European-heritage students lead to their value and behavioral differences (Fukuyama \& Greenfield, 1983; Johnson \& Marsella, 1978). Impulse control, shyness, and obedience are treated as the keywords in the upbringing of East Asian children (Chen, Rubin, \& Sun, 1992).

\section{Confucius}

In the first place, it is widely recognized that Confucius's ideology has significantly influenced Asian society, especially education (Shen, 2001; Huang \& Brown, 2009; Kang \& Chang, 2016). A large body of literature produced at the Confucius private school, such as "The Five Classics" and "The Four Books", became the teaching materials in East Asian schools for centuries, the focus of which were "effortful learning, behavioral reform, pragmatic learning, acquisition of essential knowledge, and respectful learning" (Tweed \& Lehman, 2002: p. 91). With the emphasis on the importance of diligence in the first place of study, Confucius believed that hard work could directly lead to great success. It is why Asian students often get good scores in paper examinations rather than in-class participation. Confucius also believed in "respectful learning", which requires students to respect authorities. Teachers are supposed to be the authority and model of knowledge; students should respect teachers according to Confucius' pedagogical ideology (Hofstede, 2001). Korean society also has a special cultural feature under the influence of Confucius, the concept of Chaomyon, which refers to the respect for one's status (Lee, 2009: p. 143). In other words, it indicated the hierarchical norm that the younger should respect the older. Lee (2009) men- 
tioned that Korean young people need to keep silent when older people talk, although sometimes the former may disagree with the latter (p. 143). In Korean classroom discourse, even when students are invited to ask or answer questions, the purpose is not to encourage a discussion regarding the issue but to make sure that they have understood what teachers have taught. Hence, East Asian students have gotten used to remaining quiet in class and listening to the lecture-centered class to receive knowledge passively from teachers (Hodne, 1997).

\section{Treasure of Silence}

From 1990s, the study of silence has attracted much attention in the field of language acquisition and education. From the cultural point of view, silence can be equal to a soundless response in East Asian culture. The treasure of silence has been a cultural focus. In Japan, children was taught from very young age with the traditional saying "Iwana ga han" ("Silence is better than speech") (Jones, 1999: p. 248), which shares much in common with the Chinese saying “沉默是 金” ("silence is gold."). People believe that they can avoid arguments and conflicts by maintaining silence. In this case, silence is the manifestation of harmony. The treasure of silence is based on different social or class contexts. In the educational setting, silence has its particular meaning. By observing six Korean students in an American class for 27 hours, Lee (2009) noted that all the six students can interact with teachers by some nonverbal cues like nodding and eye contact without speaking (p. 147). However, in a classroom context, instructors sometimes treat this kind of silence as disengagement, while those so-called silent students were participating through "paying attention, taking notes, or thinking about the material presented in class" (Bista, 2012: p. 77).

\section{Face}

Besides Confucius, some other traditional East Asian cultural beliefs also affect students' class performance, such as the idea of "face". One of the fundamental beliefs is the fear of "losing face" (Lee, 2019). "Face" is sometimes defined idiomatically as dignity/prestige. But it has more meaning based on Eastern cultural context. Brown and Levinson (1987) posited two types of face in Asian society, negative face and positive face. Positive face refers to one's selfesteem, while negative face refers to one's freedom to act. They summarized that positive face is threatened when an individual does not respect his or her interlocutor's self-esteem, while negative face is threatened when the listener obstructs the interlocutor's freedom of act. It is found that Chinese students liked to say yes (even they had no idea of it) if the professor asked whether they understood the content of the class or not. They are afraid of "losing face" if they say they don't understand (Lee, 2019). It is the same problem in class discussion. They hesitate to express their ideas because they are likely to feel ashamed of losing face by making mistakes in front of instructors and classmates (Huang, 2002). Here, losing face is close to losing self-esteem. A study conducted by Liu and Jackson (2008) mentioned that most students enjoyed interpersonal conversations, but refused to speak English in class because of the fear of being ne- 
gatively evaluated by teachers and classmates (p. 82).

\section{Critiques on the Effect of Cultural Differences}

Nevertheless, some research presented a different perspective: Confucianism isn't wholly confined to passive learning (e.g., Cheng, 2000; Liu \& Littlewood, 1997; Kang \& Chang, 2016; Tan, 2017). The Analects of Confucius, one of the most classic works of Confucius, emphasized the importance of asking questions and defined a teacher that the teacher is the person who teaches students knowledge, tells students the way to live, and answers students' questions. On teachers, an article written by Han Yu in Tang Dynasty, mentioned that:

Some teachers may be born before me and have learned the truth before me; I should therefore learn from them. Some may have been born after me, but learned the truth before me; I should also learn from them. As I seek the truth, I need not worry whether my teacher is my senior or junior. Whether noble or common, older or younger, whoever knows the truth can be a teacher. (Xie \& Dai, 1996: p. 302)

In other words, teachers cannot always be the authority, and students can ask and answer teachers' questions outwardly. Those words written in Confucianism's view are cited as evidence of active teaching and learning ideology in ancient China (Cheng, 2000: p. 440).

Also, it is interesting to find that low participation and silence appear to be only confined to classrooms (Tani, 2005), which cultural factors cannot explain. East Asian students are quiet, but only in class, because they are talkative after class, including interacting with other Asian students and talking with instructors during consultation hours. Paulhus et al. (2002) suspected that "Asian shyness is only a meaningful phenomenon in the mixed-ethnicity context" (p. 456).

In the meantime, some researchers have begun to critique the commonly accepted cultural labels. In the investigation of four Chinese-speaking immigrant students at a high school in California, Mckay and Wong (1996) noted that many of the Chinese immigrant parents did not fit the image of the typical timid and humble Chinese in Chinatown, however, they were coming from an aggressive, confident, industrialized, and new rich East Asia. Brought up by the new generation, students cannot be seen as what the cultural stereotype described. Gonzalez (1999) also mentioned, "Cultural differences have always been used as a convenient explanation for educational problems" (p. 432). Instead of looking primarily into cultural differences or mismatches, research needs to pay attention to individual differences. By analyzing the learning attitude of students from eight Asian countries and three European countries, Littlewood (2000) concludes that "there is actually less difference in attitudes to learning between Asian and European countries than between individuals within each country" (p. 31) A study about Asian students' participation in Australian university tutorials also reveals that students were influenced more by the classroom context rather than by their cultures (Marlina, 2009: p. 235). Thus, it is premature to conclude that cultural factors play a decisive role in the learning process. 


\subsection{Low Language Proficiency and Foreign Language Anxiety}

In applied linguistics, linguistic factors play an essential role in nonnative speakers' oral performance (e.g., Horwirz, Horvirz, \& Cope, 1986; Daubney, Dewaele, \& Gkonou, 2017). Although most East Asian international students have passed the TOEFL and/or GRE requirements in applying for American colleges and universities, they still have insufficient English language oral skills when dealing with some academic instructional courses (e.g., Hymes, 1972; Savignon, 1972; Swain, 2005). Most East Asian students are EFLs who had no English-speaking context when learning English, so they had no opportunities to practice listening and speaking skills before they came to the U.S. They stay quiet because they still need a long time to get used to the English context classrooms, including getting used to the different accents of professors and students. Lee (2009) found that Korean students constantly perceived their English ability to be inadequate for participating in class discussions in fast-paced interactive classrooms since they need time to translate the questions or answers in Korean and English back and force. When the students finally prepared to join the discussion, the class might already move on to another topic (p. 148).

There is a strong correlation between "students' sense of ease when speaking English" and "their self-perception of their own competence" (Liu \& Littlewood, 1997). Since second language learners' language performance has a strong relationship with inner anxiety, the theory of foreign language anxiety should be emphasized. Foreign language anxiety is defined as "the feeling of tension and apprehension specifically associated with second language contexts" (MacIntyre \& Gardner, 1994: p. 286). It is pointed out that listening and speaking are the most anxiety-provoking activities in using foreign language, which need immediate reaction, while language learners have more time to think and prepare in reading and writing.

As for the causes of foreign language anxiety, Horwitz, Horvirz and Cope (1986) proposed three main components; communication apprehension, test anxiety, and fear of negative evaluation. As language learners are not confident in their abilities in listening and speaking, they are afraid of having problems understanding others during conversation. They also don't want their teachers, classmates, or friends to view their language ability negatively. Especially in front of native speakers, language learners are eager to perform well, but they are afraid of getting negative feedback from native speakers. As for the effect of foreign language anxiety, students' confidence, self-esteem, and level of class participation are strongly influenced by anxiety (Horwitz, Horvirz, \& Cope, 1986: p. 131). Anxious students also have a great tendency to have negative attitudes towards the language classroom, volunteer to answer questions less frequently, and stay passive in classroom activities compared to others (Horwitz, Horvirz, \& Cope, 1986: p. 126).

Regarding the case of East Asian students, many studies in the field of foreign language anxiety have been conducted to address the influence of anxiety on 
students' participative performance. Five factors may lead to the language anxiety in speaking activities, including "speech anxiety and fear of negative evaluation; discomfort when speaking with native speakers; negative attitudes towards the English classroom; negative self-evaluation; and fear of failing the class/consequences of personal failure" (Mak, 2011: p. 210). Liu (2006) reports a study on anxiety in Chinese undergraduate non-English majors at three different proficiency levels. He found that students could feel anxious at any proficiency level, but the more proficient students tended to be less anxious (Liu, 2006: p. 301). It was also demonstrated in a Japanese university that English major students had a more positive attitude towards the class participation since they were more advanced language learners (King, 2013).

\subsection{Classroom Norms and Environment}

Research also tries to understand the phenomenon by looking into the national condition of East Asian countries, especially Mainland China (e.g., Liu, 2010; Li \& Li, 2021). For a country of China's population, the average class size there can be more than 50. Thus, Chinese teachers prefer students to ask or discuss issues after class to maintain class order (Liu, 2010: p. 47). Otherwise, the class will fall into chaos. To those students who have recently come to American school settings, it is not an easy task to change their profoundly rooted teaching and learning style.

Different curricula and methodologies are also treated as important factors that may influence students' participative performance. One of the main differences is the use of textbooks. According to Huang and Brown's (2009) study, approximately $79.6 \%$ of the participant reported that their professors in American classrooms did not follow the textbook in teaching, but in most countries in East Asia, the textbook is the fundamental part of the course. Even if they read the textbook carefully, they still feel unprepared because they cannot predict what professors may ask in class (p. 649). As Mak (2011) mentioned, speaking in front of the class without preparation and inadequate wait-time can cause intense anxiety (p. 202).

Moreover, teachers' and classmates' supportive feedback could encourage students' future participation, while negative responses might negatively influence them (Bao, 2020; Lee, 2009). It is also found that teacher's attitudes play a decisive role in affecting students' perceptions in participation, which suggests teachers should create a comfortable classroom environment for reticent students.

\subsection{Gender and Age}

Gender and age were taken into considerations in some studies. Lee (2009) found that the female students have a tendency to be more active than male students. One of the female participants was treated as the most frequent speaker during group discussions, even with other American students. On the contrary, a more recent study indicated that male participants reported more in-class participa- 
tion that female participants (Leraas, Kippen, \& Larson, 2018). However, in Paulhus, Duncan and Yik's (2002) study, by comparing students of Asian heritage and European heritage, they found "no consistent or sizable main effects or interactions for student gender or reporter gender" (p. 451).

In sum, with relatively small samples and few studies on the factors of gender and age, it is still open to doubt if they are the factors that can influence students' participative behavior.

\section{Accommodations}

A small but growing body of literature in the educational field has brought up various strategies to encourage nonnative speaking students to participate in class activities. Teachers should teach these East Asian students about the academic oral discourse patterns of western classrooms before going to American colleges and universities (Takahashi, 2019). Also, task design is significant in encouraging students to participate in class (Bao, 2020). Providing opportunities for students to talk in various ways has been given priority (e.g., Hodne, 1997; Liu \& Littlewoods, 1997; Jones, 1999; Bao, 2020). For teachers in higher education who are used to a lecture-centered class, initiating informal conversations can be regarded as a technique to involve reticent students (Hodne, 1997: p. 88), for instance, to walk around the classroom to ask questions of individuals randomly or arrange a one-on-one contact with students after class. The majority of quiet students are afraid of taking risks when speaking up in class (Hodne, 1997: p. 87), so what teachers need to do is to minimize their risks to make them feel more secure and comfortable by asking open-ended questions or giving enough time for them to prepare answers in pairs before speaking up in class. Some other practical implications include coping with anxiety and examining attitudes towards the learner role, using buzz groups, designing speaking tasks for success, and using feedback as an integral part of learning (Liu \& Littlewoods, 1997: p. 379). Lathrop (2013) created participation rubrics including preparation, engagement, initiative, response, and discussion to push students to participate in the class activities, so students can use the rubrics to record the number of contributions each member makes as the indication for grading ( $\mathrm{p}$. 8).

Some researchers pointed out that reticent students could express their ideas if encouraged appropriately (e.g., Hodne, 1997; Tani, 2005; Bao, 2020). In a recent study of Bao (2020), offering personal space and wait time has been treated as one of the common features that can trigger students' processing of thinking. Thus, one of the most highly recommended ways is the use of written communication in or after class. Reticent students may feel nervous about answering questions on the spur of the moment, but written feedback will provide those students the opportunity to edit or revise several times so that the content can be shaped to maximum effect. Thus, during the in-class discussion, they can refer to their written responses. Tani (2005) also put forward the idea of using written 
communication "as an additional tool to clarify material and to promote discussions" (p. 1). Since most international students have limited English competence, it is vital to give them enough time to prepare for each kind of written activity, as found by research and highlighted by Asian students themselves (Hodne, 1997: p. 87). Moreover, during the covid-19 pandemic, online learning provides a platform for East Asian students to participate in class activities. It is found that digital support strategies can better satisfied students' needs and encourage quiet and passive language students to engage in class activities and class discussions (Chiu, 2021).

\section{Gaps and Implications for Future Research}

There are several gaps in current studies. In the first place, most of the existing studies didn't pay attention to many other extrinsic factors that may affect students' performance, such as cultural shock and discomfort from the different curricula \& methodologies. Those factors could be applied not just to East Asian students, but also to international students from all around the world who enroll in the educational system of the United States for the first time. Researchers also didn't differentiate newcomers and students who had stayed in the U.S. for a long time. In future studies, researchers can select samples that have already become accustomed to western curricula and instruction. When researching the cultural factors, it is also valuable to compare East Asian international students with American-born East-heritage students to find out the influence of the nurturing process and environment on students' participative performance. Furthermore, the majority of the target students in current studies are students in universities. As more and more East Asian students come to the U.S. for high school study, it is necessary to conduct research on students in other age and language levels.

Moreover, few studies paid attention to the effects of American educational policy and racial justice on the performance of reticent students. Although educators and policymakers address the importance of racial justice at school, there are still many cultural and communication issues that E.L.L.s and their teachers are likely to encounter. Thus, it is crucial to figure out how educational policy and racial justice issues influence students' participative performance.

Some data in the measurements are not sufficiently objective since they are self-reported and reflect a short timeline. Moreover, current studies haven't taken region variables of American colleges and universities into consideration. Most studies were conducted in one school in a particular period of time. Nevertheless, different American cultures may bring different effects on East Asian students; thus, researchers can choose samples from various colleges and universities all over the U.S. and analyze the data. Given globalization, researchers need to treat problems from a developmental point of view. Future research is needed

to continue exploring from a longitudinal research approach and throughout a full term in various class activities. 


\section{Conclusion}

East Asian international students are frequently tagged as quiet and passive in class. This paper reviewed literature in this area to find out the possible causes and solutions to this problem. It is widely acknowledged that foreign language anxiety played a distinct role in influencing students' willingness to speak in class. Many studies demonstrate the influence of cultural factors on students' performance, including Confucius, the treasure of silence and face-saving in Asian cultures. But some researchers posit a different point of view; cultural differences are not the primary cause of educational problems. Besides, many other factors can lead to students' current condition, including lack of experience in speaking English, different classroom norms and environment, gender, and age. As for the accommodations to this specific group of students, written communication should be put in the first place since this can give students enough preparation time and minimize students' fear of taking risks. Online learning tools can also help encourage students' engagement in class activities and discussions. Lastly, although we always treat East Asian students as reticent, timid, and unsociable, sometimes it might be a stereotype. In the future, it is valuable to conduct more studies to find out the actual condition of East Asian students. Thus, there is always room to go further.

\section{Conflicts of Interest}

The author declares no conflicts of interest regarding the publication of this paper.

\section{References}

Bao, D. (2020). 2. Silence, Talk and In-Betweens: East Asian Students' Responses to Task Challenge in an Australian University. In East Asian Perspectives on Silence in English Language Education (pp. 17-36). Multilingual Matters. https://doi.org/10.21832/9781788926775-007

Biggs, J. B. (1991). Approaches to Learning in Secondary and Tertiary Students in Hong Kong: Some Comparative Studies. Educational Research Journal, 6, 27-39.

Bista, K. (2012). Silence in Teaching and Learning: Perspectives of a Nepalese Graduate Student. College Teaching, 60, 76-82. https://doi.org/10.1080/87567555.2011.633943

Brown, P., \& Levinson, S. (1987). Politeness: Some Universals in Language Use. Cambridge University Press. https://doi.org/10.1017/CBO9780511813085

Chen, X., Rubin, K. H., \& Sun, Y. (1992). Social Reputation and Peer Relationships in Chinese and Canadian Children: A Cross-Cultural Study. Child Development, 63, 1336-1343. https://doi.org/10.2307/1131559

Cheng, X. T. (2000). Asian Students' Reticence Revisited. System, 28, 435-446. https://doi.org/10.1016/S0346-251X(00)00015-4

Chiu, T. K. (2021). Applying the Self-Determination Theory (SDT) to Explain Student Engagement in Online Learning during the COVID-19 Pandemic. Journal of Research on Technology in Education, 1-17. https://doi.org/10.1080/15391523.2021.1891998

Choi, S. H. J., \& Nieminen, T. A. (2013). Factors Influencing the Higher Education of International Students from Confucian East Asia. Higher Education Research \& Devel- 
opment, 32, 161-173. https://doi.org/10.1080/07294360.2012.673165

Daubney, M. A. R. K., Dewaele, J. M., \& Gkonou, C. (2017). Preliminary Thoughts on Language Anxiety and the Focus of This Anthology. In New Insights into Language Anxiety: Theory, Research and Educational Implications (pp. 1-7). Multilingual Matters. https://doi.org/10.21832/9781783097722-002

Fukuyama, M. A., \& Greenfield, T. K. (1983). Dimensions of Assertiveness in an AsianAmerican Student Population. Journal of Counseling Psychology, 30, 429-432. https://doi.org/10.1037/0022-0167.30.3.429

Gonzalez, N. (1999). What Will We Do When Culture Does Not Exist Anymore? Anthropology \& Education Quarterly, 30, 431-435. https://doi.org/10.1525/aeq.1999.30.4.431

Hodne, B. D. (1997). Please Speak Up: Asian Immigrant Students in American College Classrooms. New Directions for Teaching and Learning, 1997, 85-92. https://doi.org/10.1002/tl.7010

Hofstede, G. H. (2001). Culture's Consequences: Comparing Values, Behaviors, Institutions and Organizations across Nations. Sage.

Horwitz, E. K., Horwitz, M. B., \& Cope, J. (1986). Foreign Language Classroom Anxiety. The Modern Language Journal, 70, 125-132. https://doi.org/10.1111/j.1540-4781.1986.tb05256.x

Huang, H. M. (2002). Toward Constructivism for Adult Learners in Online Learning Environments. British Journal of Educational Technology, 33, 27-37. https://doi.org/10.1111/1467-8535.00236

Huang, J., \& Brown, K. (2009). Cultural Factors Affecting Chinese E.S.L. Students' Academic Learning. Education, 129, 643-653.

Hymes, D. (1972). On Communicative Competence (Vol. 35). In J. B. Pride, \& J. Holmes (Eds.), Sociolinguistics (pp. 269-293). Penguin.

Institute of International Education (2020). Open Doors Report on International Educational Exchange. http://www.iie.org/opendoors

Johnson, F. A., \& Marsella, A. J. (1978). Differential Attitudes toward Verbal Behavior in Students of Japanese and European Ancestry. Genetic Psychology Monographs, 97, 4376.

Jones, J. F. (1999). From Silence to Talk: Cross-Cultural Ideas on Students Participation in Academic Group Discussion. English for Specific Purposes, 18, 243-259. https://doi.org/10.1016/S0889-4906(97)00059-8

Kang, H., \& Chang, B. (2016). Examining Culture's Impact on the Learning Behaviors of International Students from Confucius Culture Studying in Western Online Learning Context. Journal of International Students, 6, 779-797. https://doi.org/10.32674/jis.v6i3.356

Kim, S. (2006). Academic Oral Communication Needs of East Asian International Graduate Students in Non-Science and Non-Engineering Fields. English for Specific Purposes, 25, 479-489. https://doi.org/10.1016/j.esp.2005.10.001

King, J. (2013). Silence in the Second Language Classrooms of Japanese Universities. Applied Linguistics, 34, 325-343. https://doi.org/10.1093/applin/ams043

Lathrop, A. H. (2013). Teaching How to Question: Participation Rubrics. http://www.bgsu.edu/downloads/provost/file116040.pdf

Lee, G. (2009). Speaking Up: Six Korean Students' Oral Participation in Class Discussions in U.S. Graduate Seminars. English for Specific Purposes, 28, 142-156.

https://doi.org/10.1016/j.esp.2009.01.007 
Lee, J. S. (2019). EFL Students' Views of Willingness to Communicate in the Extramural Digital Context. Computer Assisted Language Learning, 32, 692-712. https://doi.org/10.1080/09588221.2018.1535509

Leraas, B. C., Kippen, N. R., \& Larson, S. J. (2018). Gender and Student Participation. Journal of the Scholarship of Teaching and Learning, 18, 51-70. https://doi.org/10.14434/josotl.v18i4.22849

Li, X., \& Li, M. (2021). The Effect of Large and Small Class Size in Compulsory Education in China. Rangsit Journal of Educational Studies, 8, 46-58.

Littlewood, W. (2000). Do Asian Students Really Want to Listen and Obey? E.L.T. Journal, 54, 31-36. https://doi.org/10.1093/elt/54.1.31

Liu, J. (2010). Negotiating Silence in American Classrooms: Three Chinese Cases. Language and Intercultural Communication, 2, 37-54. https://doi.org/10.1080/14708470208668074

Liu, M. (2006). Anxiety in Chinese EFL Students at Different Proficiency Levels. System, 34, 301-316. https://doi.org/10.1016/j.system.2006.04.004

Liu, M., \& Jackson, J. (2008). An Exploration of Chinese EFL Learners' Unwillingness to Communicate and Foreign Language Anxiety. The Modern Language Journal, 92, 7186. https://doi.org/10.1111/j.1540-4781.2008.00687.x

Liu, N. F., \& Littlewood, W. (1997). Why Do Many Students Appear Reluctant to Participate in Classroom Learning Discourse? System, 25, 371-384.

https://doi.org/10.1016/S0346-251X(97)00029-8

MacIntyre, P. D., \& Gardner, R. C. (1994). The Subtle Effects of Language Anxiety on Cognitive Processing in the Second Language. Language learning, 44, 283-305. https://doi.org/10.1111/j.1467-1770.1994.tb01103.x

Mak, B. (2011). An Exploration of Speaking-in-Class Anxiety with Chinese E.S.L. Learners. System, 39, 202-214. https://doi.org/10.1016/j.system.2011.04.002

Marginson, S. (2011). The Confucian Model of Higher Education in East Asia and Singapore. Higher Education, 61, 587-611. https://doi.org/10.1007/s10734-010-9384-9

Marlina, R. (2009). “I Don’t Talk or I Decide Not to Talk? Is It My Culture?”-International Students' Experiences of Tutorial Participation. International Journal of Educational Research, 48, 235-244. https://doi.org/10.1016/j.ijer.2009.11.001

McKay, S. L., \& Wong, S. L. C. (1996). Multiple Discourses, Multiple Identities: Investment and Agency in Second-Language Learning among Chinese Adolescent Immigrant Students. Harvard Educational Review, 66, 577-606. https://doi.org/10.17763/haer.66.3.n47r06u264944865

Paulhus, D. L., Duncan, J. H., \& Yik, M. S. (2002). Patterns of Shyness in East-Asian and European-Heritage Students. Journal of Research in Personality, 36, 442-462. https://doi.org/10.1016/S0092-6566(02)00005-3

Rošker, J. S. (2017). Between Tradition and Modernity: Modern Confucianism as a Form of East Asian Social Knowledge. Asian Studies, 5, 43-62. https://doi.org/10.4312/as.2017.5.2.43-62

Savignon, S. J. (1972). Communicative Competence: An Experiment in Foreign-Language Teaching. Center for Curriculum Development.

Shen, J. (2001). Confucius, 551-479 B.C.E. In J. A. Palmer (Ed.), Fifty Major Thinkers on Education: From Confucius to Dewey (pp. 1-4). Routledge. https://doi.org/10.4324/9780203467121-1

Swain, M. (2005). The Output Hypothesis: Theory and Research (pp. 495-508). Routledge. https://doi.org/10.4324/9781410612700-38 
Takahashi, J. (2019). East Asian and Native-English-Speaking Students' Participation in the Graduate-Level American Classroom. Communication Education, 68, 215-234. https://doi.org/10.1080/03634523.2019.1566963

Tan, C. (2017). A Confucian Conception of Critical Thinking. Journal of Philosophy of Education, 51, 331-343. https://doi.org/10.1111/1467-9752.12228

Tani, M. (2005). Quiet, But Only in Class: Reviewing the In-Class Participation of Asian Students. In Higher Education Research and Development Society of Australia Conference (Vol. 5, p. 2007). http://conference.herdsa.org.au/2005/pdf/non refereed/030.pdf

Tani, M. (2008). Raising the In-Class Participation of Asian Students through a Writing Tool. Higher Education Research \& Development, 27, 345-356. https://doi.org/10.1080/07294360802406817

Tsui, A. B. M. (1996). Reticence and Anxiety in Second Language Learning. In K. Bailey, \& D. Nunan (Eds.), Voices from the Language Classroom (pp. 145-167). Cambridge University Press.

Tweed, R. G., \& Lehman, D. R. (2002). Learning Considered within a Cultural Context: Confucian and Socratic Approaches. American Psychologist, 57, 88-99.

https://doi.org/10.1037/0003-066X.57.2.89

Wang, H. (2006). What Matters and Why? PAACE Journal of Lifelong Learning, 15, 6984.

Xie, B., \& Dai, K. (1996). On Teachers. In 100 Chinese Prose Writing through the Ages (pp. 301-302). China Translation and Publishing Corporation. 